\title{
OPTIMALISASI PRESTASI BELAJAR BAHASA INDONESIA SISWA MELALUI PENERAPAN MODEL PEMBELAJARAN MASTERY LEARNING DENGAN MEDIA LKS
}

\author{
Ketut Karpini \\ SMP Negeri 3 Banjarangkan \\ Email: Karpini71@gmail.com
}

\begin{abstract}
ABSTRAK
Penelitian ini adalah penelitian tindakan kelas yang bertujuan untuk mengetahui apakah penerapan model pembelajaran Mastery Learning dengan media LKS dapat meningkatkan prestasi belajar siswa kelas VII C pada semester I tahun pelajaran 2017/2018 di SMP Negeri 3 Banjarangkan. Penelitian yang dilakukan sesuai tujuan di atas menggunakan tes prestasi belajar sebagai metode pengumpulan datanya dan menggunakan analisis deskriptif untuk menganalisis data hasil penelitian. Setelah dilakukan analisis diperoleh peningkatan hasil dari data awal yang rataratanya 64,77 dengan ketentuan belajar 45,45\% meningkat pada siklus I menjadi 69,91 rata-ratanya dengan ketuntasan belajar 68,18\% dan pada siklus II meningkat lagi rata-rata kelasnya menjadi 81,36 dengan ketuntasan belajar 95,45\%. Hasil tersebut telah membuktikan keberhasilan penelitian yang dilakukan sehingga dapat disimpulkan bahwa model pembelajaran Mastery Learning dengan media LKS mampu meningkatkan prestasi belajar siwa. Hasil itu telah membuktikan bahwa hipotesis yang disampaikan dapat diterima.
\end{abstract}

Kata kunci: $\quad$ prestasi belajar, model pembelajaran Mastery Learning, media LKS

\section{ABSTRACT}

This research is a classroom action research that aims to find out whether the application of the Mastery Learning model with the media LKS can improve student achievement in class VII C in the first semester of the academic year 2017/2018 in SMP Negeri 3 Banjarangkan. Research conducted in accordance with the objectives above uses learning achievement tests as a method of data collection and uses descriptive analysis to analyze research data. After analyzing the results obtained an increase in the initial data average of 64,77 with the provisions of learning 45,45\% increased in the first cycle to 69,91 on average with mastery learning 68,18\% and the second cycle increased the class average of 81,36 with the provisions of learning 95,45\%. These results have proven the success of the research conducted so that it can be concluded that the learning model of Mastery Learning with LKS media is able to improve student achievement. The results have proven that the hypothesis presented is acceptable.

Keywords: learning achievement, Mastery Learning Model, LKS Media

\section{PENDAHULUAN}

Guru sebagai pendidik yang profesional, dalam melaksanakan tugasnya harus giat dalam melakukan sesuatu agar prestasi belajar siswa dapat ditingkatkan. Untuk hal tersebut dituntut keuletan, keilmuan, kemampuan, kecekatan dalam merencanakan dan mengaplikasikan apa yang telah dibuat sesuai perencanaan.Mengajarkan bahasa tidak dapat hanya menggunakan satu metode saja karena karena bahasa bersifat dinamis. Bahasa sendiri bukan sebagai ilmu tetapi sebagai keterampilan sehingga penggunaan metode yang tepat perlu dilakukan.

Pembelajaran Bahasa Indonesia di lembaga pendidikan formal sangat mengandalkan penggunaan metode-metode yang aplikatif dan menarik. Pembelajaran yang menarik akan memikat siswa untuk terus dan betah mempelajari bahasa sebagai alat berkomunikasi. Apabila siswa sudah 
Jurnal Santiaji Pendidikan, Volume 10, Nomor 2, Juli 2020 ISSN 2087-9016, e-ISSN 2685-4694

tertarik dengan pembelajaran maka akan dengan mudah meningkatkan prestasi siswa dalam bidang Bahasa Indonesia. Di sebagian siswa, pembelajaran Bahasa Indonesia sangat membosankan karena mereka sudah merasa bisa dan penyampaian materi yang kurang menarik sehingga secara tidak langsung siswa menjadi lemah dalam penangkapan materi tersebut. Peneliti sebagai guru Bahasa Indonesia sangat merasakan problem pembelajaran yang terjadi selama ini.

Dari hasil pengamatan awal terhadap prestasi belajar Bahasa Indonesia siswa kelas VII C SMP Negeri 3 Banjarangkanrata-rata baru tercapai 64,77 dimana hanya $45,45 \%$ (10 siswa) dari 22 siswa yang dinilai sudah memenuhi persyaratan nilai KKM (Kriteria Ketuntasan Minimal). Nilai KKM yang dipersyaratkan untuk mata pelajaran Bahasa Indonesia adalah70,00.

Permasalahan tersebut terjadi karena rendahnya kesiapan siswa untuk mengikuti pelajaran, ini terlihat dari siswa kurang aktif mengikuti kegiatan belajar mengajar pada awal proses pembelajaran. Siswa yang kemampuannya kurang, terlihat belum siap belajar yang ditandai siswa tersebut sedikit malas untuk mengerjakan apa yang diperintahkan oleh guru. Siswa tidak mempunyai motivasi dalam mengikuti proses pembelajaran.

Seorang guru harus mampu menerapkan suatu model pembelajaran yang dapat memberikan solusi terhadap permasalahan yang ada di kelas. Model pembelajaran merupakan cara untuk dapat melakukan sesuatu yang lebih baik. Seorang guru harus pandai memilih model pembelajaranyang sesuai dengan pokok bahasan yang akan disampaikan. Apabila guru mampu memilih dan menerapkan model pembelajarandengan baik, maka sudah dapat dipastikan hasil belajar siswa akan mampu ditingkatkan.

Salah satu pendekatan pembelajaran yang diduga mampu mewujudkan situasi pembelajaran yang kondusif; aktif, kreatif, efektif, dan menyenangkan adalah model pembelajaranMastery Learning. Melalui penggunaan pendekatan ini dalam pembelajaran, para siswa SMPakan mampu menumbuhkembangkan potensi intelektual, sosial, dan emosional yang ada dalam dirinya, sehingga kelak mereka mampu berkomunikasi dan berinteraksi sosial secara matang, arif, dan dewasa. Selain itu, mereka juga akan terlatih untuk mengemukakan gagasan dan perasaan secara cerdas dan kreatif, serta mampu menemukan dan menggunakan kemampuan analitis dan imajinatif yang ada dalam dirinya dalam menghadapi berbagai persoalan yang muncul dalam kehidupan sehari-hari.

Berdasarkan latar belakang dan masalah yang berhasil diidentifikasi menyangkut belum berhasilnya siswa mencapai ketuntasan belajar yang diinginkan dan upaya pemecahan yang akan dilakukan, maka peneliti berhasil merumuskan masalah dalam penelitian ini sebagai berikut: Apakah prestasi belajar Bahasa Indonesia dapat ditingkatkan dengan menerapkan langkah-langkah model pembelajaran Mastery Learningdengan media LKS kelas VII Csemester Itahun pelajaran2017/2018 di SMP Negeri 3 Banjarangkan?Tujuan penelitian sangat penting dirumuskan dengan tepat. Untuk merumuskan dengan tepat alur latar belakang masalah dan rumusan tujuan perlu menjadi perhatian. Atas dasar keilmuan tersebut maka tujuan penelitian ini dirumuskan yaitu :Untuk mengetahui seberapa tinggi peningkatan prestasi belajar Bahasa Indonesia akan 
Jurnal Santiaji Pendidikan, Volume 10, Nomor 2, Juli 2020 ISSN 2087-9016, e-ISSN 2685-4694

terjadi setelah menggunakan model pembelajaran Mastery Learningdengan media LKSsiswa kelas VII C semester I tahun pelajaran 2017/2018 di SMP Negeri 3 Banjarangkan.Setiap kegiatan penelitian tentu diupayakan untuk dapat bermanfaat. Dengan demikian maka manfaat penelitian ini diharapkan dapat dirasakan bagi berbagai kalangan, seperti : 1) Bagi siswa, lebih mudah menguasai materi pelajaran dan lebih mudah mengingatnya, sehingga prestasi belajar siswa akan dapat meningkat. 2) Bagi guru, merupakan alternatif strategi penanggulangan permasalahan pembelajaran di kelas dalam upaya pembelajaran Bahasa Indonesia. 3) Bagi sekolah, memperkaya strategi peningkatan kualitas lulusan di sekolah.

Prestasi belajar berasal dari kata "prestasi" dan "belajar". Prestasi berarti hasil yang telah dicapai sedangkan belajar adalah berusaha memperoleh kepandaian/ilmu (Depdiknas, 2011).

Prestasi belajar Bahasa Indonesia sama dengan prestasi belajar bidang studi yang lain merupakan hasil dari proses belajar siswa dan sebagaimana biasa dilaporkan pada wali kelas, murid dan orang tua siswa setiap akhir semester atau akhir tahun pelajaran.

Prestasi belajar mempunyai arti dan manfaat yang sangat penting bagi anak didik, pendidik, orang tua/wali murid dan sekolah, karena nilai atau angka yang diberikan merupakan manifestasi dari prestasi belajar siswa dan berguna dalam pengambilan keputusan atau kebijakan terhadap siswa yang bersangkutan maupun sekolah. Prestasi belajar merupakan kemampuan siswa yang dapat diukur, berupa pengetahuan, sikap dan keterampilan yang dicapai siswa dalam kegiatan belajar mengajar.
Djamarah (1994) mendefinisi-kan prestasi belajar sebagai hasil yang diperoleh berupa kesan-kesan yang mengakibatkan perubahan dalam diri individu sebagai hasil dari aktivitas dalam belajar. Kalau perubahan tingkah laku adalah tujuan yang mau dicapai dari aktivitas belajar, maka perubahan tingkah laku itulah salah satu indikator yang dijadikan pedoman untuk mengetahui kemajuan individu dalam segala hal yang diperolehnya di sekolah. Dengan kata lain prestasi belajar merupakan kemampuankemampuan yang dimiliki oleh siswa sebagai akibat perbuatan belajar atau setelah menerima pengalaman belajar, yang dapat dikatagorikan menjadi tiga ranah, yakni ranah kognitif, afektif, dan psikomotor.

Dengan mengkaji hal tersebut di atas, maka faktor-faktor yang dapat mempengaruhi prestasi belajar antara lain: (1) faktor yang ada pada diri organisme itu sendiri yang dapat disebut faktor individual, seperti kematangan/pertumbuhan, kecerdasan, latihan, motivasi, dan faktor pribadi, (2) faktor yang ada diluar individu yang disebut faktor sosial, seperti faktor keluarga/keadaan rumah tangga, guru dan cara mengajamya, alat-alat yang dipergunakan dalam belajar-mengajar, lingkungan dan kesempatan yang tersedia dan motivasi sosial(Purwanto, 2012). Dalam penelitian ini faktor ke 2 yaitu faktor yang dari luar seperti guru dan cara mengajarnya yang akan menentukan prestasi belajar siswa. Guru dalam hal ini adalah kemampuan atau kompetensi guru, pendidikan dan lain-lain. Cara mengajarnya itu merupakan faktor kebiasaan guru itu atau pembawaan guru itu dalam memberikan pelajaran. Juga dikatakan oleh Slamet (2003) bahwa faktor-faktor yang 
Jurnal Santiaji Pendidikan, Volume 10, Nomor 2, Juli 2020 ISSN 2087-9016, e-ISSN 2685-4694

mempengaruhi belajar banyak jenisnya, tetapi dapat digolongkan menjadi dua golongan saja, yaitu faktor intern dan faktor ekstem. Faktor intern diklasifikasi menjadi tiga faktor yaitu: faktor jasmaniah, faktor psikologis dan faktor kelelahan. Faktor jasmaniah antara lain: kesehatan, cacat tubuh. Faktor psikologis antara lain: intelegensi, perhatian, minat, bakat, motif, kematangan, kesiapan. Faktor kelelahan antara lain: kelelahan jasmani dan rohani. Sedangkan faktor ekstern digolongkan menjadi tiga faktor yaitu: faktor keluarga, faktor sekolah, faktor masyarakat. Faktor keluarga antara lain: cara orang tua mendidik, relasi antara keluarga, suasana rumah tangga dan keadaan ekonomi keluarga. Faktor sekolah antara lain: metode mengajar, kurikulum, relasi guru dengan siswa, relasi siswa dengan siswa, disiplin sekolah, pelajaran dan waktu sekolah, standar pelajaran, keadaan gedung, metode belajar dan tugas rumah. Faktor masyarakat antara lain: kegiatan siswa dalam masyarakat, mass media, teman bergaul, bentuk kehidupan masyarakat. Peningkatan prestasi belajar yang penulis teliti dalam hal ini dipengaruhi oleh factor ekstern yaitu metode mengajar guru.

Prestasi belajar sangat vital dalam dunia pendidikan, mengingat prestasi belajar itu dapat berperan sebagai hasil penilaian dan sebagai alat motivasi(Sadirman, 2011). Adapun peran sebagai hasil penilaian dan sebagai alat motivasi diuraikan seperti berikut.

Dalam pembahasan sebelumnya telah dibicarakan bahwa prestasi belajar adalah hasil penilaian pendidikan tentang kemajuan prestasi siswa setelah melakukan aktivitas belajar. Ini berarti prestasi belajar tidak akan bisa diketahui tanpa dilakukan penilaian atas hasil aktivitas belajar siswa. Fungsi prestasi belajar bukan saja untuk mengetahui sejauhmana kemajuan siswa setelah menyelesaikan suatu aktivitas, tetapi yang lebih penting adalah sebagai alat untuk memotivasi setiap siswa agar lebih giat belajar, baik secara individu maupun kelompok. Dalam pembahasan ini akan dibicarakan mengenai prestasi belajar sebagai hasil penilaian dan pada pembahasan berikutnya akan dibicarakan pula prestasi belajar sebagai alat motivasi. Prestasi belajar sebagai hasil penilaian sudah dipahami. Namun demikian untuk mendapatkan pemahaman, perlu juga diketahui, bahwa penilaian adalah sebagai aktivitas dalam menentukan rendahnya prestasi belajar itu sendiri.

Dari uraian di atas, dapat disimpulkan bahwa prestasi belajar adalah semua hasil yang dicapai siswa setelah melakukan kegiatan belajar yang berbentuk angka sebagai simbol dari ketuntasan belajar bidang studi.

Model pembelajaranmastery learning atau yang dalam bahasa Indonesianya disebut pembelajaran tuntas adalah salah satu usaha dalam pendidikan yang bertujuan untuk memotivasi peserta didik mencapai penguasaan (mastery level) terhadap kompetensi tertentu. Dengan menerapkan strategi pembelajaran tuntas dalam proses pembelajaran merupakan salah satu pendukung utama dalam pelaksanaan kurikulum berbasis kompetensi, berarti pembelajaran tuntas merupakan sesuatu yang harus dipahami dan dilaksanakan dengan sebaik-baiknya oleh seluruh warga sekolah secara tuntas, jika ada yang masih tertinggal maka guru harus melaksanakan suatu upaya pemberian perlakuan khusus untuk membantu anak tersebut mengejar ketertinggalannya dalam penguasaan materi atau suatu kompetensi. Dengan demikian semua anak baik yang pintar ataupun yang kurang dapat 
Jurnal Santiaji Pendidikan, Volume 10, Nomor 2, Juli 2020 ISSN 2087-9016, e-ISSN 2685-4694

menguasai kompetensi yang dipersyaratkan dengan baik.

Perbedaan antara pembelajaran tuntas dengan pembelajaran konvensional adalah bahwa pembelajaran tuntas dilakukan melalui asas-asas ketuntasan belajar, sedangkan pembelajaran konvensional pada umumnya kurang memperhatikan ketuntasan belajar khususnya ketuntasan peserta didik secara individual.

Ahmadi, dkk. (2005) mengemukakan ada beberapa ciri belajar tuntas (mastery learning), yaitu: 1)Siswa dapat belajar dengan baik dalam kondisi pengajaran yang tepat sesuai dengan harapan pengajar; 2) Bakat seorang siswa dalam bidang pengajaran dapat diramalkan, baik tingkatannya maupun waktu yang dibutuhkan untuk mempelajari bahan tersebut. Bakat berfungsi sebagai indeks tingkatan belajar siswa dan sebagai suatu ukuran satuan waktu; 3) Tingkat hasil belajar bergantung pada waktu yang digunakan secara nyata oleh siswa untuk mempelajari sesuatu dibandingkan dengan waktu yang dibutuhkan untuk mempelajarinya; 4) Tingkat belajar sama dengan ketentuan, kesempatan belajar bakat, kualitas pengajaran, dan kemampuan memahami pelajaran; 5) Setiap siswa memperoleh kesempatan belajar yang berdiferensiasi dan kualitas pengajaran yang berdiferensiasi pula.

Para pengembang konsep belajar tuntas mendasarkan pengembangan pengajarannya pada prinsip-prinsip sebagai berikut: 1) Sebagian besar siswa dalam situasi dan kondisi belajar yang normal dapat menguasai sebagian terbesar bahan yang diajarkan. Tugas guru untuk merancang pengajarannya sedemikian rupa sehingga sebagian besar siswa dapat menguasai hampir seluruh bahan ajaran; 2)
Guru menyusun strategi pengajaran tuntas mulai dengan merumuskan tujuan-tujuan khusus yang hendak dikuasai oleh siswa;3) Sesuai dengan tujuan-tujuan khusus tersebut guru merinci bahan ajar menjadi satua-satuan bahan ajaran yang kecil yang medukung pencapaian sekelompok tujuan tersebut; 4) Selain disediakan bahan ajaran untuk kegiatan belajar utama, juga disusun bahan ajaran untuk kegiatan perbaikan dan pengayaan. Konsep belajar tuntas sangat menekankan pentingnya peranan umpan balik; 5) Penilaian hasil belajar tidak menggunakan acuan norma, tetapi menggunakan acua patokan; 6) Konsep belajar tuntas juga memperhatikan adanya perbedaan-perbedaan individual (Sukmadinata, dan Syaodih, 2005).

Menurut Darmodjo dan Kaligis (1992), LKS atauLembar Kerja Siswa merupakan sarana pembelajaran yang dapat digunakan gurudalam meningkatkan keterlibatan atau aktivitas siswa dalam proses belajar-mengajar.Pada umumnya, LKS berisi petunjuk praktikum, percobaan yang bisa dilakukan dirumah, materi untuk diskusi, Teka Teki Silang, tugas portofolio, dan soal-soal latihan,maupun segala bentuk petunjuk yang mampu mengajak siswa beraktivitas dalamproses pembelajaran(Salirawati, 2004)

LKS adalah suatu cara bagi guru untuk berkomunikasi dengan siswasecara aktif. Oleh karena itu LKS yang dapat menunjang komunikasi dengansiswa SD haruslah sederhana. Dalam LKS guru perlu menggunakan kalimat-kalimatyang tidak terlalu panjang, tidak rumit, dengan katakata sederhana yangmudah dipahami siswa serta kalimat posistif. Bila perlu sertakan pula gambarpada petunjuk atau alat dan bahan yang akan digunakan seperti kalimat rumpangpada pelajaran bahasa Indonesia, terutama LKS yang diperuntukkan bagi 
Jurnal Santiaji Pendidikan, Volume 10, Nomor 2, Juli 2020 ISSN 2087-9016, e-ISSN 2685-4694

siswakelas 1 dan 2. Bagi siswa kelas 3 hingga kelas 6 yang sudah terampil membaca,gambar dapat meningkatkan motivasi siswa untuk melakukan eksplorasi. Gambaryang dicantumkan pada LKS di kelas tinggi bukan merupakan petunjuk, tetapidigunakan sebagai pemikat.

Pengertian lain tentang LKS disampaikan oleh Astuti (2011) yang menyatakan LKS adalah kertas yang berisi tugas-tugas atau rencana kerja atau langkah-langkah kegiatan yang mengarahkan siswa untuk mempelajari bab yang ada di buku ajar dan mengerjakannya.

LKSadalah salah satu alternatif pembelajaran yang tepat bagi peserta didik karena LKS membantu peserta didik untuk menambah informasi tentang konsep yang dipelajari melalui kegiatan belajar secara sistematis(Suyitno, 2004).

Dalam satu kelas sering dijumpai siswa yang belum terampil dalammembaca. Bagi kelas yang demikian, kelompokkanlah siswa ini dengan siswayang sudah terampil membaca, atau bila LKS dikerjakan secara individual, makapasangkanlah dengan teman yang terampil membaca. Siswa yang terampilmembaca akan sangat membantu baik bagi siswa yang belum terampil membacamaupun bagi guru. Tetapi guru juga dapat membantu siswa yang belum terampilmembaca dengan menjadikan satu kelompok, kemudian guru membantumembacakan aktivitas yang harus dilakukan oleh siswa dalam kelompok tersebut,sehingga tidak mengganggu siswa yang sudah terampil membaca.

\section{METODOLOGI PENELITIAN}

Sekolah yang dipergunakan sebagai lokasi penelitian tindakan kelas ini adalah SMP Negeri 3 Banjarangkan. Situasi sekolah yang sejuk dan rindang karena banyak pohon tumbuh di halaman sekolah.Rancangan penelitian mempunyai manfaat yang besar bagi kelancaran sebuah penelitian. Rancangan penelitian memberi pegangan yang jelas kepada peneliti dalam melakukan penelitian. Untuk itu, peneliti memilih rancangan yang dibuat oleh Arikunto (Arikunto, 2006). Peneliti menentukan memilih rancangan tersebut maka pelaksanaannya dilakukan dengan :Mulai dengan adanya suatu permasalahan. Setelah diketahui ada masalah, dibuat perencanaan, kemudian dilaksanakan, diamati dan dilakukan refleksi. Setelah refleksi akan terlihat permasalahan yang tersisa yang merupakan masalah baru. Dengan adanya masalah baru maka dibuat perencanaan ulang, dilaksanakan, diamati dan dilakukan refleksi. Bila permasalahan belum bisa diatasi maka dilanjutkan dengan siklus berikutnya.

Semua siswa kelas VII Csemester Itahun pelajaran 2017/2018 merupakan subjek dalam penelitian ini yang berjumlah 22 orang siswa.Objek penelitian ini adalah peningkatan prestasi belajar siswa kelas VII Csemester I tahun pelajaran2017/2018di SMP Negeri 3 Banjarangkan setelah diterapkan model pembelajaran Mastery Learningdengan media LKS dalam pembelajaran.Penelitian ini dilakukan dari bulan Juli 2017 sampai bulan Nopember 2017. Tes adalah metode yang digunakan untuk mengumpulkan data dalam penelitian ini.Yang dipergunakan untuk menganalisis data hasil penelitian ini adalah analisis deskriptif. Untuk data kuantitatif dianalisis dengan mencari mean, median, modus, membuat interval kelas dan melakukan penyajian dalam bentuk tabel dan grafik.

\section{HASIL DAN PEMBAHASAN Hasil Penelitian}


Jurnal Santiaji Pendidikan, Volume 10, Nomor 2, Juli 2020 ISSN 2087-9016, e-ISSN 2685-4694

Pelaksanaan yang dilakukan dalam kegiatan awalmemperoleh hasil prestasi belajar Bahasa Indonesia yang masih rendah yaitu baru memperoleh nilai 64,77 dimana 6 orang $(27,27 \%)$ memperoleh nilai diatas KKM, 4 orang $(18,18 \%)$ memperoleh nilai sama dengan KKM sedangkan 12 orang $(54,55 \%)$ memperoleh nilai di bawah KKM. Ketidakberhasilan tersebut banyak dipengaruhi oleh faktor ketidaksiapan guru dalam membuat perencanaan, profesionalisme guru dalam melaksanakan pembelajaran dan kesiapan guru dalam mempelajari keilmuankeilmuan yang mesti ditetapkan dalam melaksanakan proses pembelajaran. Peneliti sebagai guru di SMP Negeri 3 Banjarangkan telah berupaya semaksimal mungkin agar peningkatan mutu pendidikan di sekolah ini dapat berjalan sesuai harapan.

Tabel 1. Data Kelas Interval Siklus I

\begin{tabular}{|c|c|c|c|c|}
\hline $\begin{array}{l}\text { No } \\
\text { Urut }\end{array}$ & Interval & $\begin{array}{c}\text { Nilai } \\
\text { Tengah }\end{array}$ & $\begin{array}{c}\text { Frekuensi } \\
\text { Absolut }\end{array}$ & $\begin{array}{c}\text { Frekuensi } \\
\text { Relatif }\end{array}$ \\
\hline 1 & $60-64$ & 62 & 3 & 13,64 \\
\hline 2 & $65-69$ & 67 & 4 & 18,18 \\
\hline 3 & $70-74$ & 72 & 9 & 40,91 \\
\hline 4 & $75-79$ & 77 & 5 & 22,73 \\
\hline 5 & $80-84$ & 82 & 0 & 0,00 \\
\hline 6 & $85-89$ & 87 & 1 & 4,55 \\
\hline & Total & & 22 & 100 \\
\hline
\end{tabular}

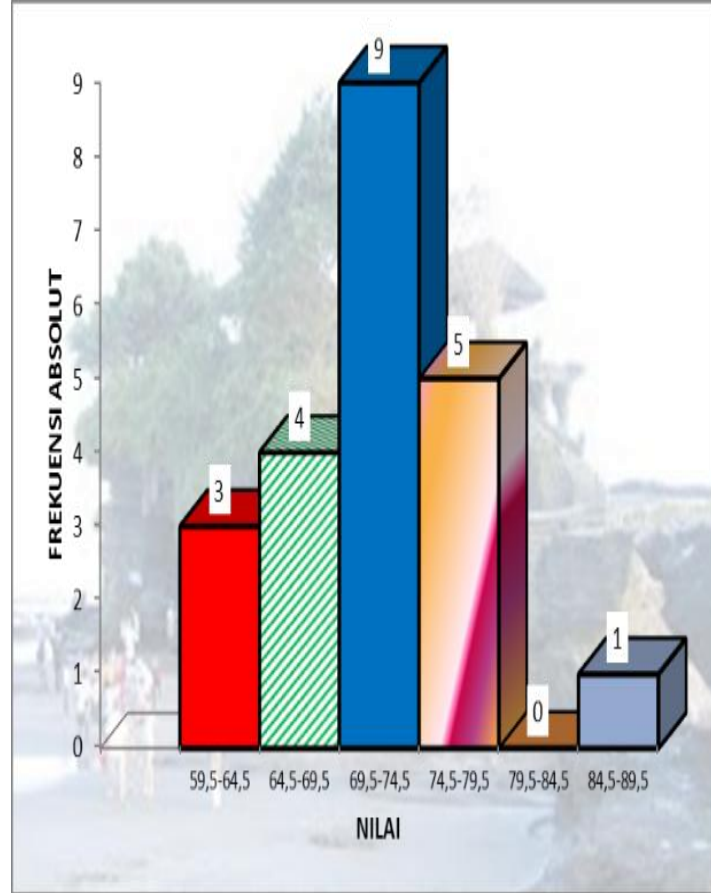

Gambar 1. Histogram Siklus I

Analisis kuantitatif Prestasi belajar siswa siklus II dimana rata-rata (mean) : 81,36. Median (titik tengah) : 80,00. Modus (angka yang paling banyak/paling sering muncul) : 80,00.

Tabel 2. Data Kelas Interval Siklus II

\begin{tabular}{|c|c|c|c|c|}
\hline $\begin{array}{l}\text { No } \\
\text { Urut }\end{array}$ & Interval & $\begin{array}{c}\text { Nilai } \\
\text { Tengah }\end{array}$ & $\begin{array}{c}\text { Frekuensi } \\
\text { Absolut }\end{array}$ & $\begin{array}{c}\text { Frekuensi } \\
\text { Relatif }\end{array}$ \\
\hline 1 & $65-69$ & 67 & 1 & 4,55 \\
\hline 2 & $70-74$ & 72 & 1 & 4,55 \\
\hline 3 & $75-79$ & 77 & 4 & 18,18 \\
\hline 4 & $80-84$ & 82 & 7 & 31,82 \\
\hline 5 & $85-89$ & 87 & 3 & 13,64 \\
\hline 6 & $90-94$ & 92 & 6 & 27,27 \\
\hline \multicolumn{3}{|c|}{ Total } & 22 & 100 \\
\hline
\end{tabular}




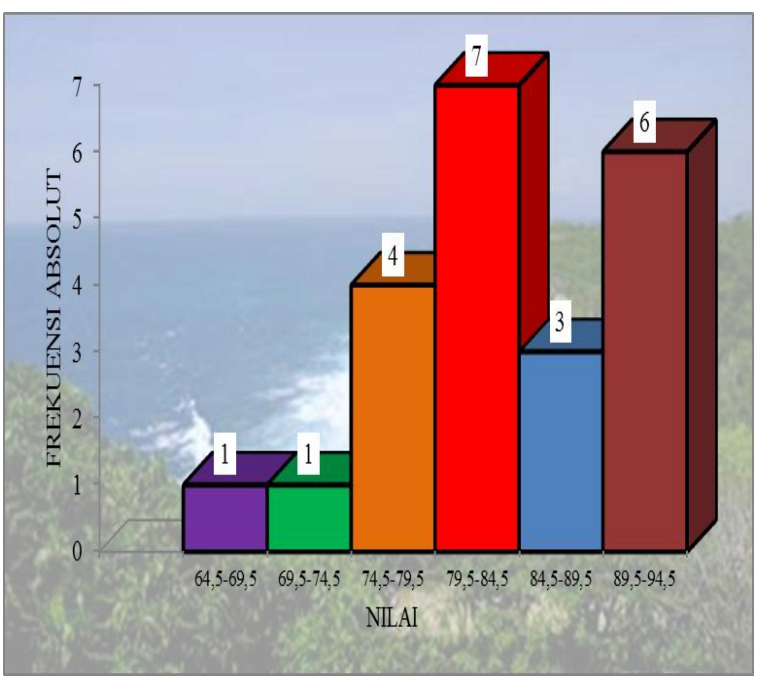

Gambar 2. Histogram Siklus II

\section{Pembahasan}

Data awal yang diperoleh dengan rata-rata64,77 menunjukkan bahwa kemampuan siswa dalam mata pelajaran Bahasa Indonesia masih sangat rendah mengingat kriteria ketuntasan belajar siswa untuk mata pelajaran ini di SMP Negeri 3 Banjarangkan adalah 70,00. Dengan nilai yang sangat rendah seperti itu maka peneliti mengupayakan untuk dapat meningkatkan prestasi belajar Bahasa Indonesia siswa menggunakan model pembelajaran Mastery Learning dengan media LKS. Akhirnya dengan penerapan model pembelajaran Mastery Learning dengan media LKS yang benar sesuai teori yang ada, peningkatan rata-rata prestasi belajar Bahasa Indonesia siswa pada siklus I dapat diupayakan dan mencapai ratarata69,91. Namun rata-rata tersebut belum maksimal karena hanya7 siswa $(31,82 \%)$ yang belum mencapai KKM. Sedangkan prosentase ketuntasan belajar mereka baru mencapai68,18\%. Hal tersebut terjadi akibat penggunaan model pembelajaran Mastery Learning dengan media LKS belum maksimal dapat dilakukan disebabkan penggunaan model tersebut baru dicobakan sehingga guru masih belum mampu melaksanakannya sesua alur teori yang benar.

Pada siklus ke II perbaikan prestasi belajar siswa diupayakan lebih maksimal dengan peneliti membuat perencanaan yang lebih baik, menggunakan alur dan teori dari model pembelajaran Mastery Learning dengan media LKS dengan benar dan lebih maksimal. Peneliti giat memotivasi siswa agar giat belajar, memberi arahan-arahan, menuntun mereka untuk mampu menguasai materi pelajaran pada mata pelajaran Bahasa Indonesia lebih optimal. Akhirnya dengan semua upaya tersebut peneliti mampu meningkatkan prestasi belajar siswa pada siklus II menjadi rata-rata81,36 dengan prosentase ketuntasan belajar siswa sudah tercapai $94,45 \%$. Upaya-upaya yang maksimal tersebut menuntun pada suatu keberhasilan bahwa model pembelajaran Mastery Learning dengan media LKS mampu meningkatkan prestasi belajar Bahasa Indonesia siswa.

\section{SIMPULAN DAN SARAN}

Pelaksanaan kegiatan awal dimana model pembelajaran yang digunakan tidak menentu, termasuk pula metode ajar yang digunakan hanya sekedar terlaksana membuat nilai siswa pada mata pelajaran Bahasa Indonesia rendah dengan rata-rata 64,77 yang masih jauh dari kriteria ketuntasan minimal (KKM) pada mata pelajaran Bahasa Indonesia yaitu 70,00. Dimana dari 22 orang siswa yang diteliti ada 6 orang siswa $(27,27 \%)$ memperoleh nilai di atas KKM, 4 orang siswa $(18,18 \%)$ memperoleh nilai sama dengan KKM dan sisanya sebanyak 12 orang siswa $(54,55 \%)$ masih memperoleh nilai di bawah KKM dan dinyatakan tidak tuntas.

Setelah dilakukan perencanaan yang lebih matang menggunakan model pembelajaran Mastery Learningdengan 
Jurnal Santiaji Pendidikan, Volume 10, Nomor 2, Juli 2020 ISSN 2087-9016, e-ISSN 2685-4694

media LKS, dilanjutkan dengan pelaksanaannya di lapangan yang benar sesuai teori yang ada dan dibarengi dengan pemberian tes atau observasi secara objektif akhirnya terjadi peningkatan dari nilai rata-rata awal menjadi rata-rata 69,91.

Dimana pada siklus I dari 22 orang siswa yang diteliti ada 7 orang siswa $(31,82 \%)$ memperoleh nilai di atas KKM, 8 orang siswa $(36,36 \%)$ memperoleh nilai sama dengan KKM dan sisanya sebanyak 7 orang siswa $(31,82 \%)$ masih memperoleh nilai di bawah KKM dan dinyatakan tidak tuntas. Demikian juga terjadi peningkatan dari nilai rata-rata siklus I meningkat menjadi 81,36 pada siklus II. Dimana pada siklus II dari 22 orang siswa yang diteliti ada 20 orang siswa $(90,91 \%)$ memperoleh nilai di atas KKM, 1 orang siswa $(4,55 \%)$ memperoleh nilai sama dengan KKM dan masih ada seorang siswa $(4,55 \%)$ masih memperoleh nilai di bawah KKM dan dinyatakan tidak tuntas tetapi tidak mempengaruhi indikator keberhasilan penelitian.

Seperti kebenaran tujuan pelaksanaan Penelitian Tindakan Kelas (PTK) yaitu untuk peningkatan proses pembelajaran, maka upaya-upaya yang maksimal telah dilakukan dengan sangat giat sehingga hasil yang diharapkan sesuai perolehan data telah mampu memberi jawaban terhadap rumusan masalah dan tujuan penelitian ini.

Dari hasil penelitian yang diperoleh dari uraian sebelumnya agar proses belajar mengajar di SMPNegeri 3 Banjarangkan lebih efektif dan lebih memberikan hasil yang optimal bagi siswa, maka disampaikan saran sebagai berikut : 1) Untuk melaksanakan pembinaan memerlukan persiapan yang cukup matang, sehingga disarankan agar guru mampu menentukan atau memilih topik yang benar-benar bisa diterapkan dengan model pembelajaran Mastery Learning dengan media LKSsehingga diperoleh hasil yang optimal. 2) Agar mampu meningkatkan prestasi belajar Bahasa Indonesia, maka guru hendaknya lebih sering melatih siswa dengan kegiatan penemuan, walau dalam taraf yang sederhana, agar para siswa menjadi berminat terhadap kegiatan yang dilakukan sehingga keaktifan belajar akan meningkat. 3) Peneliti lain diharapkan melakukan penelitian lebih lanjut untuk meneliti bagian-bagian yang belum sempat diteliti.

\section{DAFTAR PUSTAKA}

Arikunto, S. (2006). Prosedur Penelitian Tindakan Kelas. Bumi Aksara.

Purwanto, M. P. (2012). Metodologi Penelitian Kuantitatif untuk Psikologi dan Pendidikan. In Yogyakarta: Pustaka Pelajar.

Sadirman. (2011). Keguruan dan Ilmu Kependidikan. Interakasi Dan Motivasi Belajar-Mengajar.

Salirawati, D. (2004). Penyusunan dan Kegunaan LKS Dalam Proses Pembelajaran. Jurrnal Online. https://doi.org/10.1021/ic034857j

Suyitno, A. (2004). Dasar-dasar dan Proses Pembelajaran Matematika I. Semarang: UNNES. 